\title{
"Opisto vetää puoleensa vaihtoehtoisen arjen tavoittelijoita"
}

\author{
Vaasalainen väitöskirjatutkija Annika Pastuhov \\ tutkii osallistumista vapaaseen sivistystyöhön.
}

MINUSTA TULI TUTKIJA sattumalta ja uteliaisuudesta, mutta ennen muuta, koska kerran aloitettu väitöskirjatyö vei mennessään haasteista huolimatta. Olen vain jatkanut jatko-opiskelijan taivaltani, vaikka en vieläkään ole vakuuttunut valintani järkevyydestä. Aloitin väitöstutkimukseni Åbo Akademissa viitisen vuotta sitten, ja väitöstilaisuus on sovittu helmikuulle.

JOS EN TUTKISI, keksisin ihan varmasti jotakin muuta tekemistä. Ehkä työskentelisin edunvalvontatehtävissä jossain ammattiliitossa tai olisin kouluttautunut sairaanhoitajaksi tai tulkiksi.

AIKUISKASVATUSTIEDETTÄ TARVITAAN yhteiskunnassa, koska on tärkeä pohtia ja kyseenalaistaa aikuisuuden ja kasvun ehtoja ajassamme: Keitä me olemme? Mistä tulemme? Mihin olemme menossa? Miksi?

Entä miten rakennamme luottamusta tutkittuun tietoon? Miten voisimme avata epistemologisia ja ontologisia kysymyksiä suurelle yleisölle, jotta ihmisten olisi helpompaa suhtautua tarkoituksenmukaisesti tieteelliseen tietoon?

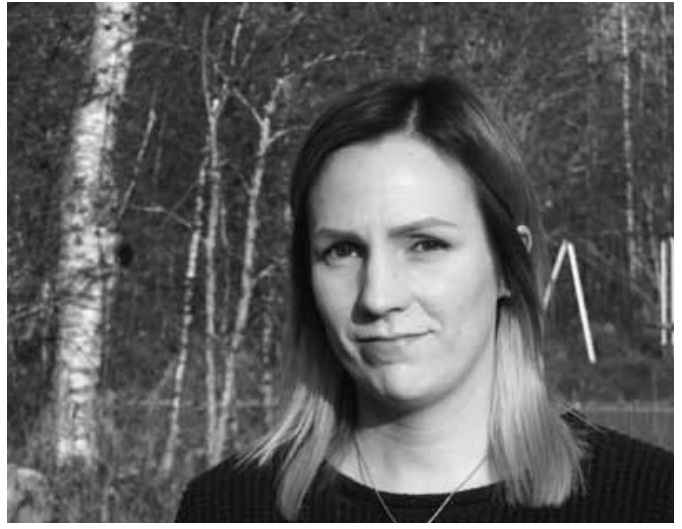

Pidän huomionarvoisena, kuinka kattava luottamus meidän Åbo Akademin jatko-opiskelijoiden kesken on vuosien mittaan syntynyt", väitöskirjatutkija Annika Pastuhov kertoo.

PARAIKAA TUTKIN osallistumista vapaan sivistystyön kursseille kansalaisuusnäkökulmasta etnografisella otteella. Olen osallistunut havainnoijana kolmelle kurssille, ja pohdin, miten kansalaiskasvatuksen ideaali toteutuu käytännössä. 
Osallistuminen vapaaseen sivistystyöhön näyttäytyy väitöskirjatutkimuksessani mahdollisuutena tavoitella sellaista arkea, joka ei elämässä muuten toteutuisi. Millä ehdoilla vaihtoehtoista arkea tavoitellaan? Vapaa sivistystyö sinällään ei näytä vaikuttavan tavoitteenasetteluun, kun vaihtoehtoja tavoitellaan samanmielisten kanssa.

Linköpingin yliopiston tutkijana tutkin sikäläisen vapaan sivistystyön suhdetta maahanmuuttajiin ja maahanmuuttajayhdistyksiin. Kollegani, ItäSuomen yliopiston tutkijan Ari Siveniuksen kanssa tutkin etnografista tietoa ja sen reunaehtoja.

Esikuvanani pidän monia ihmisiä. Haluan olla tutkija, joka suhtautuu nöyrästi omaan panokseensa sitä silti vähättelemättä. Ihailen ihmisiä, jotka ovat samaan aikaan teräviä ja myötätuntoisia ja jotka ovat vakuuttuneita omasta jutustaan mutta silti arvostavat toisten näkemyksiä.

SEURAAVAKSI TUTKIN väitöskirjani viitoittamana tematiikkaa, joka koskee vapaata sivistystyötä, etnografista tietoa ja kansalaisuutta. Minua kiinnostaa myös tarkastella vapaan sivistystyön tutkimusta eri konteksteissa. Lisäksi olen kiinnostunut kotoutumisen ja siirtolaisuuden kysymyksistä.

Kun en tutki, olen mieluiten rauhassa kotosalla, lenkkeilen koiran kanssa tai vietän koti-iltaa mieheni kanssa tai puuhailen kavereideni kanssa. Arvostan mielekästä ja riittävää vapaa-aikaa: On hyvä pohtia elämän merkitystä mutta vielä tärkeämpää on olla kiinni arjessa.

\section{Verkostoni}

Åbo Akademin kasvatustieteiden jatko-opiskelijat on aktiivinen porukka. Järjestämme opintopiirejä, luemme ja kommentoimme toistemme tekstejä, käymme syömässä ja kahvittelemme. Arvostan jatko-opiskelijakollegoitani todella paljon. Olen kiitollinen heiltä saamastani tuesta ja iloinen, kun välillä itsekin pystyn auttamaan toisia.
Mimer on Ruotsin eduskunnan rahoittama ja Linköpingin yliopiston ylläpitämä vapaan sivistystyön tutkimusverkosto, jonka kautta olen saanut kollegoja Pohjoismaista. Varsinkin Mimerin vuotuinen konferenssi on tärkeä kohtaamispaikka.

Sivistystyön vapaus ja vastuu -ohjelma eli SVV on tutustuttanut minut suomalaisiin tutkijakollegoihin. 